\title{
Kardos, Klára. 2020. The Auschwitz Journal. A Catholic Story from the Camps. Trans. Fr. Julius D. Lelocky, O. Cist. Brewster: Paraclete Press [Auschwitz napló. Budapest: Szent Gellért Kiadó, 2001 http://www.ppek.hu/konyvek/Kardos_Klara_Auschwitzi_naplo_1.pdf.]
}

\author{
Reviewed by Louise O. Vasvári, Stony Brook University and NYU lvasvari@icloud.com
}

When the twenty-seven-year old survivor of Buchenwald Elie Wiesel met the seventy-year-old French writer and Catholic ethicist, François Mauriac, it was a meeting of like minds, for both Wiesel and Mauriac were concerned with the misery of man living in the absence of God. At the same time the conversation between them revealed a great theological divide between Jews and Christians. For Mauriac the center of Wiesel's story was the power of love and suffering in Christ, as he sought to reinterpret the Holocaust for a renewed understanding of Christianity, in which the survivor represented the ultimate witness. Since in Judaism there is no such equivalence between suffering and love, the cornerstone of Mauriac's faith was a stumbling block to Weisel's own faith. The two writers nevertheless established a deep friendship and in 1958 Mauriac made possible the publication of the French translation of Wiesel's Yiddish memoir as La nuit (English translation, The Night, 1960), which became one of the bedrocks of Holocaust literature.

In the same year of the appearance of Wiesel's eventual international bestseller, a devoutly Catholic Hungarian woman, Klára Kardos (1920-1984), deported as a Jew to Auschwitz, wrote her own camp memoir, which, however, was not published until seventeen years after her death. She never sought to publish it in her lifetime: she felt that while she was able to recount some of the horrors of Auschwitz, what remained incomprehensible to others who did not have the same devotion was the édes paradoxon ['sweet paradox'] of the happiness in suffering she had experienced (a concept she called szépen szenvedni ['to suffer in beauty'] in another writing). Mauriac would certainly have understood Kardos's enigmatic spirituality but it is doubtful that Weisel would have, or that most "real" Jews (as Kardos refers to them in her memoir) who survived similar experiences would either.

Klára Kardos's parents were both Jewish but her mother converted before her birth, so that she herself was a "cradle Catholic," baptized at birth. Kardos was born in Nagykanizsa, where after their parents' divorce she and her younger sister were brought up by their mother. 
Vasvári, Louise O. "Kardos, Klára. 2020. The Auschwitz Journal. A Catholic Story from the Camps. Trans. Fr. Julius D. Lelocky, O. Cist. Brewster: Paraclete Press [Auschwitz napló. Budapest: Szent Gellért Kiadó, 2001 http://www.ppek.hu/konyvek/Kardos_Klara_Auschwitzi_naplo_1.pdf.]" Hungarian Cultural Studies. e-Journal of the American Hungarian Educators Association, Volume 14 (2021) DOI: 10.5195/ahea.2021.455

She was educated in Catholic schools and graduated in 1942 from the University of Szeged with a Hungarian-Latin-Italian major. She also knew English and French, and later translated from these languages. (In preparing this review I found in the Helen Keller archives a letter from Kardos to Keller in 1960, where she writes in beautiful English that she had first read Keller's autobiography when she was only fourteen and learning English, and she was asking for permission to translate it to Hungarian.)

Kardos's greatest lifelong intellectual and theological influence was Sándor Sík (18891963), the Piarist Order's highest representative in Hungary at the time and a writer and famous professor of literature in Szeged during 1930-1944. Sík was also one of the leading Catholic poets in Hungary, and a leader in the scout movement (a Hungarian scouting park is today named after him in Fillmore, in Upstate New York). Sík's socio-cultural background was similar to that of Kardos, as his parents were Jews who had converted before his birth and he didn't learn about his Jewish origin until the age of ten. He was very critical of the fate of the Jews during the war, and he himself survived in a cloister in 1944 only as a mentesitett Jew ['with dispensation']. Nevertheless, in his diary he made clear that he felt unable to feel any fellowship with Jews and that even socially he felt them to be a botcsinálta ['pretend'] community. Sík was also the teacher in Szeged of Miklós Radnóti(1909-1944) and the priest who conducted Radnoti's and his wife's conversion in 1943. For both Sík and Radnóti assimilation was in part the Catholic religion, but also the Hungarian intellectual and literary life, and this was likely the case for Kardos as well. (Radnóti is considered one of the greatest Hungarian poets of the twentieth-century and is recognized as one of the most important poetic witnesses to the Holocaust. He was murdered on a death march as a Jew, but his widow who only died in 2014 at the age of 102, never allowed his poetry to be published in any collection of Jewish poetry.)

Kardos had an early vocation for religion and by the seventh grade had memorized the Latin text of the ordinary parts of the mass, as well as many prayers. After graduating from university she also attended the Ward Kollegium, an order named after Ward Maria (1585-1645), which in 1916 became an independent Hungarian order in Hungary and ran a college to train female teachers of religion. After surviving the war Kardos was for a time a gimnazium teacher in village schools but under communism was fired for "unreliability" due to her religious convictions. Subsequently she supported herself through typing and translation work. From 1947 through 1970 she also published regularly in Vigilia, the most important Hungarian Catholic literary and cultural journal, of which Sándor Sík was the editor for some time. After constantly being hounded by the police due to her samizdat activities, in 1970 Kardos managed to escape to Austria. There she worked in Klagenfurt for Szolgálat, a Jesuit quarterly journal and publisher of books of theology and spirituality, which were both utilized by Hungarian Jesuits doing pastoral work in Hungarian communities outside of Hungary and smuggled into Hungary. Kardos lived a very ascetic life, completely dedicating herself to writing, editing, and translating religious texts until her death in 1984 of brain cancer.

Although days after liberation Kardos briefly began to keep a journal, she subsequently avoided talking about her wartime experiences, until friends urged her to write her memoir, which she did in 1958. At that time such a work could not in any case be published in Hungary but, as mentioned, she did not aim to publish it even after she lived in Austria, and it was published only seventeen years after her death and translated to English for a wider audience only in 2020. Abbot Denis Farkasfalvy, O. Cist., who wrote the Foreword to the English translation and who had known Kardos well in Austria, states that he knew nothing of her 
Vasvári, Louise O. "Kardos, Klára. 2020. The Auschwitz Journal. A Catholic Story from the Camps. Trans. Fr. Julius D. Lelocky, O. Cist. Brewster: Paraclete Press [Auschwitz napló. Budapest: Szent Gellért Kiadó, 2001 http://www.ppek.hu/konyvek/Kardos_Klara_Auschwitzi_naplo_1.pdf.]" Hungarian Cultural Studies. e-Journal of the American Hungarian Educators Association, Volume 14 (2021) DOI: 10.5195/ahea.2021.455

deportation until reading her posthumous memoir. In her memoir Kardos details the usual horrors of deportation, such as her ghettoization in Szeged with some 11,000 Jews, the deportation in cattle-cars to Auschwitz, and the details of the shock of the initial period after arrival. Rather than dwelling on her suffering in the camp, she writes in a very matter-of-fact style, sometimes as an observant describing the camp routines.

For one who has read many accounts of similar women's camp experiences it is of particular interest to note those experiences that Kardos describes in a way significantly different from that of most inmates, thus reflecting her spiritual understanding of suffering. For example, she states simply of when she was tattooed: "A11248 - this is what I would be from then on" (96). At the same time, she comments that she could not understand why so many women said that if they survived they would have their tattoos removed after the war, tattoos that in any case would leave a telltale scar and that she herself wore proudly. She also describes that upon arrival at Auschwitz others feverishly tried to put on all their clothes with the hope of being able to preserve them, while she, who had already chosen to travel very lightly, tore into little pieces the last postcard from her family and her sister's photograph and poured out the last of the jam she had brought with her and even threw away the bottle, to prevent them getting into the unsacred hands of her captors. Interestingly, she does not discuss the horrors of the selection process, probably because her own family had been deported from Nyiregyháza, while she alone was deported from Szeged and was thus not separated from her family members on arrival (it was only after liberation that she found out they had been killed on arrival). Many women have described the toll the shaving of their hair had on their sense of self, but Kardos details with more attention also that the length of hair regrown by inmates in the camp meant not only a more feminine appearance but also indicated longer camp experience, as she could see among the women from Transylvania and Upper Hungary, who had been there since spring 1944 (because Hungarian deportations had started from those areas). While many have described how they initially refused to believe the Slovak and Polish kapos telling them that their relatives had been gassed on arrival, Kardos claims that she continued to refuse to believe the crematoria were in operation until she had returned home and come upon incontrovertible evidence. As I have studied elsewhere (and here at https://ahea.pitt.edu/ojs/index.php/ahea/article/view/322/630), starving women in camps constantly talked about food and recipes, which Kardos does mention, but for her this kind of occupation was annoying because she says that she herself did not have these kinds of material needs, so that in the camps she did not actually feel the starvation. Yet she does admit that after liberation no amount of food seemed enough and that by then she, too, developed this kind of food fantasizing.

Kardos explains that throughout her deportation she preserved her faith but that it was also her faith that preserved her, explicitly making clear that she consciously accepted the cross of participation in the suffering of Christ. She states that she wants to write down how she and her camp sisters tried to remain human in the midst of inhuman circumstances and how she found expressions of love when they were least expected. Throughout the memoir, she follows the stages of her Calvary, noting the dates according to the Catholic calendar, for example, recording her arrival as Wednesday, June 28, the morning of the eve of the Feast of Saint Peter and Paul. Every Sunday she and her fellow Catholics gathered in the morning hours to celebrate mass, which she was able to lead because she had memorized so many parts of the mass, as well as many prayers. The worshippers even had a sermon and at the end of the service, a recitation from the best religious poems of Hungarian literature, from Balassi and Berzsenyi, and including 
Vasvári, Louise O. "Kardos, Klára. 2020. The Auschwitz Journal. A Catholic Story from the Camps. Trans. Fr. Julius D. Lelocky, O. Cist. Brewster: Paraclete Press [Auschwitz napló. Budapest: Szent Gellért Kiadó, 2001 http://www.ppek.hu/konyvek/Kardos_Klara_Auschwitzi_naplo_1.pdf.]" Hungarian Cultural Studies. e-Journal of the American Hungarian Educators Association, Volume 14 (2021) DOI: 10.5195/ahea.2021.455

contemporary works. In their barracks they would recite the Rosary to the rhythm of the raindrops pouring in through the leaky roof. From the beginning Kardos also sought to develop her spiritual life in isolation by walking meditation, when possible. In the absence of the possibility of Holy Communion this spiritual communion became her daily bread, in addition to her "pastoral" apostolic activities with several camp sisters.

Mention must also be made of Kardos's stated relationship with those whom she referred to as the "real" Jews in the camp. Unlike her teacher Sík, she did not set out to present a coherent philosophy of her attitude toward her Jewish origin, but she does provide, scattered throughout her memoir, comments about her interactions with Jewish inmates. For example, she writes of what she perceived as her double "persecution," not only by the Nazis but also by Jews, who blamed Christian Jews as traitors. She cites several examples of animosity from other prisoners, the first occurring in the brick factory in Szeged when valuables were being confiscated from the Jews. The person charged with taking possession of her fountain pen and wristwatch was so shocked to see that the watch had on its face painted the picture of the Sacred Heart of Jesus, that she questioned Kardos about why she was there and then secretly returned her both the watch and the pen. But, a few days later the watch was stolen, which is the first of a few mentions on the theme of the lack of sympathy of "real" Jews for the Christians: "oh, how many times will they show themselves worse than the enemy" (36). And yet at another point she says she can't remember any adverse criticism for being Christian (79).

Perhaps what most shows the emotional distance between Kardos and Jewish inmates is when she recounts how wonderful it was when she met three other Christian women in Auschwitz, and the four of them formed a bond and managed to remain together on the subsequent transport as slave laborers to the German munitions camp in Salzwedel. The formation of spiritual camp sisterhoods was of course very common and literally lifesaving for many, but Kardos criticizes her Jewish fellow inmates, including those "on whom Christianity was only an external varnish," among whom she claims real friendships were few (86-87), an opinion that merely shows that she and those inmates did not establish much confraternity. Kardos's charge of "external varnish" is a reference to those Jews who had converted either for social reasons or in a mistaken hope to save themselves by doing so. There was, in fact, plenty of prejudice to go around, but much of it was more likely directed against the thousands of new Christian converts than against a small and marginal group of devout Catholics. Note the example recounted by Jewish writer Ernő Szép (1884-1953), in his 1945 Emberszag ['Scent of Humans'], recounting his life in a Budapest starred house in 1944, about Christian Jewish women flaunting large crosses next to their yellow star and attending Catholic services in the starred houses, who were quickly dubbed csillagkeresztes hölgyek ['ladies of the starry cross'] (https://magyarnemzet.hu/lugas-rovat/csillagkeresztes-holgyek-az-ovodaban-7693091/). The joke is very meaningful because of the reference to the Order of the Starry Cross, an imperial Austrian dynastic order of Catholic noble ladies, founded in 1668 in the Austrian Empire, where the members had to prove an adequate number of nobles on both paternal and maternal lines. Compare also György Moldova's 1981 autobiographical novel, Szent Imre induló ['St. Emmerich March'], where the Jewish first-person narrator says that the gentiles called converts romai zsidok ['Roman Jews'] and that he himself felt trembling disgust for those Jews trying to convert, and not because he himself was religious but as a non-believer whose father was a Social Democrat. 
Vasvári, Louise O. "Kardos, Klára. 2020. The Auschwitz Journal. A Catholic Story from the Camps. Trans. Fr. Julius D. Lelocky, O. Cist. Brewster: Paraclete Press [Auschwitz napló. Budapest: Szent Gellért Kiadó, 2001 http://www.ppek.hu/konyvek/Kardos_Klara_Auschwitzi_naplo_1.pdf.]" Hungarian Cultural Studies. e-Journal of the American Hungarian Educators Association, Volume 14 (2021) DOI: 10.5195/ahea.2021.455

Kardos and her three camp sisters were transferred to Bergen-Belsen and from there to Salzwedel, a small town between Hanover and Hamburg, where they arrived on her birthday on October 7. They worked in twelve-hour shifts in the Draht- und Metallfabrik Salzwedel munitions factory, part of the Neugamme concentration camp complex, which produced infantry ammunition. Kardos writes that she was never able to determine the number of women inmates in Salzwedel, but in fact most of the 1,520 women in this all-women camp came from Hungary, with some others from Poland and Greece. There is today in the United States Holocaust Memorial Museum a manuscript containing testimonies of forty women survivors of Salzwedel, collected during a 1996 survivors' meeting. Only recently, on the seventy-fifth anniversary of the liberation of Auschwitz I also read about a ninety-six-year-old survivor of Salzwedel, Evelyn Lipmann, who had just received the covid vaccine in the same arm where she still had tattooed the number A25466.

The inmates in Salzwedel had the luck that their camp was the only one in the Neugamme constellation that did not have to be evacuated but instead prisoners from two other satellite camps were evacuated into their camp, increasing their number to some 3,000, but avoiding a death march. The camp was liberated by the Americans on April 19, 1945. The Americans gave permission for the prisoners to loot whatever they wanted in town during twenty-four hours. But Kardos recounts that the first instinct she and her closest camp sister had upon being liberated was to go into town and find a Catholic Church, make confession, and take communion. They then find shelter in a house whose inhabitants had fled, where her friend fills up a suitcase with women's clothing and other items, at which point Kardos realizes that they must now part ways. She herself leaves behind even the eraser and a few other items she had picked up, and she makes her way home with a halfway-filled burlap sack and two gray blankets, feeling that God had his intentions for her in her new life.

The translation into English of Klara Kardos's Auschwitz Diary is most welcome, as her life of both exemplary religious devotion and sustained intellectual activity is of interest not only for believers, but also for students of Hungarian Studies, Gender Studies, and of Religious Philosophy more broadly. Modern female spirituality of the cross, especially in confrontation with the Holocaust, has to date only been studied through the life of a few outstanding figures, such as Simone Weil and Edith Stein. On the martyrdom of Stein and other Christian Jews in the camps see Father Paul Haman (Edith Stein and Companions on the Way to Auschwitz. San Francisco: Ignatius, 2010), who discusses the fate of one hundred and thirteen victims, several of them priests and nuns, exterminated in Auschwitz and other camps. Most had become Catholic, in adult age, the most famous among them being Stein, a Carmelite nun who was later canonized as Saint Teresa Benedicta, and whose sister was also murdered. Father Haman argues against those who claim that such Christian Jews could not be considered martyrs for the faith since they would in any case have been killed as Jews.

For the consideration of Hungarian women of Jewish birth who became devout Catholics, I suggest also the study by János Kőbányai, (“Ö él.” Múlt és Jövő 1991.4: 75-85), about the conversion story of a Catholic Jewish nun he met in Israel. By way of comparison, it would also be relevant to consider the more numerous cases of those Holocaust survivors who became Messianic Jews who follow Christ, or Evangelical Christians. See Marianne Fischer (19242015), Time of Storm: The Harrowing True Story of a Jewish Christian Woman in Wartime Hungary (Chappaqua: Christian Herald Books, 1981; published in the original Hungarian in 1998), as well as the dual memoirs of two other women also about the same age as Kardos, 
Vasvári, Louise O. "Kardos, Klára. 2020. The Auschwitz Journal. A Catholic Story from the Camps. Trans. Fr. Julius D. Lelocky, O. Cist. Brewster: Paraclete Press [Auschwitz napló. Budapest: Szent Gellért Kiadó, 2001 http://www.ppek.hu/konyvek/Kardos_Klara_Auschwitzi_naplo_1.pdf.]" Hungarian Cultural Studies. e-Journal of the American Hungarian Educators Association, Volume 14 (2021) DOI: 10.5195/ahea.2021.455

Marianne Adam (1923-?) and Ella Böhm Salomon (1920-2002), who became Christians subsequent to their survival and who view their lives as a double miracle, a miracle that they survived and a second miracle that it was not hatred that won in their hearts but a long road to reconciliation, which led both to Jesus Christ; and all this in spite of the fact that both were witnesses in the Auschwitz Trials of 1964 in Frankfurt (Was wird der Morgen bringen? Zwei Jüdinnen überleben Auschwitz und finden zum Glauben an Jesus Christus. Stuttgart: Edition Anker, 1995, translated from Hungarian by Moshe Fogel, reedited 2001). 